\title{
E-LEARNING: Meningkatkan Pemahaman Peserta Didik Mengenai Teks Eksplanasi Dengan Self Paced Learning
}

\author{
Yana Lisa Warni \\ E-mail : yanalisawarni@gmail.com \\ Program Studi Pendidikan Bahasa dan Sastra Indonesia
}

\section{Pengantar}

Pendidikan merupakan salah satu aspek terpenting yang dibutuhkan oleh manusia. Dengan adanya pendidikan, manusia diajarkan tentang keterampilan, pengetahuan, serta bagaimana cara agar manusia dapat meningkatkan kemampuan berpikir kritis. Dalam Permendikbud No. 103 tahun 2014 pasal 2 ayat 1 tercantum bahwa pembelajaran dilaksanakan berbasis aktivitas dengan karakteristik interaktif, inspiratif, kontekstual kolaboratif, menyenangkan, menantang, dan memotivasi serta memberikan ruang yang cukup bagi prakarsa, kreativitas dan kemandirian peserta didik sesuai dengan bakat, minat, kemampuan, dan perkembangan fisik serta psikologis peserta didik. Pendidikan sendiri dapat diperoleh dari berbagai tempat, salah satunya sekolah sebagai lembaga formal. Sekolah diawasi oleh tenaga pendidik dalam meningkatkan mutu sumber daya manusia yaitu peserta didik. Proses yang ditempuh peserta didik untuk meningkatkan mutunya menempuh perjalanan yang panjang. Peserta didik diajarkan bagaimana cara bersikap, memiliki moral yang baik serta memiliki tingkat pengetahuan yang nantinya dapat dipergunakan dalam berkehidupan di masyarakat. Dalam bidang studi dan mata pelajaran Bahasa Indonesia sendiri terdapat banyak sub materi yang perlu dipelajari, salah satunya mengenai teks eksplanasi. Menurut pendapat (Anjani, 2021) teks eksplanasi merupakan teks yang menguraikan serangkaian peristiwa. Teks eksplanasi juga memiliki fungsi sosial yaitu memberikan penjelasan kepada masyarakat mengenai proses terjadinya sesuatu. Dengan mempelajari teks eksplanasi akan membantu dan melatih peserta didik agar mampu berpkir kritis dengan membuat arguentasi, mengumpulkan data yang faktual. Biasanya saat sekolah siswa akan banyak menerima penjelasan materi secara langsung oleh guru bidang studi. Namun, sejak Maret 2020 pembelajaran tatap muka serta segala aktivitas yang dilakukan terpaksa dihentikan sementara yang diakibatkan oleh virus covid-19 yang mewabah kemudian diganti dengan sistem yang dilakukan secara online. Sekolah-sekolah melaksanakan pembelajaran berbasis E-learning dengan memanfaatkan segala jenis platform pembelajaran digital yang diperlukan. Dengan pelaksanaan pembelajaran secara online, 
terdapat kendala yang dapat menghambat peserta didik dapat menerima penjelasan dari gurunya. Untuk itu, penerapan self-paced learning merupakan langkah yang dapat dilakukan untuk membantu siswa agar dapat belajar secara mandiri.

\section{Tindakan yang Dilakukan}

\section{a. E-learning}

Sistem pembelajaran di masa ini pada umumnya dilaksanakan menggunakan pembelajaran berbasis online (e-learning). Di masa covid-19, aktivitas belajar dilakukan secara daring sehingga menuntut mahasiswa belajar secara mandiri dan melatih skilnya agar dapat mencapai tujuan pembelajaran. Dalam situasi ini, mahasiswa menjadi pengontrol utama dalam aktivitas belajarnya. Maka mahasiswa perlu memilih dan memiliki metode belajar yang tepat agar kualitas belajarnya stabil (Zulhafizh, 2020). Hal ini tentu tidak hanya dialami oleh mahasiswa yang berada pada tingkat universitas, melainkan siswa sekolah dasar dan menengah pun mengalami hal yang sama.

Hal ini tidak selalu berdampak buruk pada perkembangan anak dalam memperoleh pemahaman terkait materi yang di ajarkan. E-learning mendukung peserta didik agar lebih rileks dalam menerjakan soal, serta memahami materi yang diajarkan. Hal ini dikarenakan e-learning menggunakan sistem pembelajaran yang mana peserta didik dapat belajar dimana pun dengan nyaman. Berdasarkan pendapat (Hartanto, 2016) manfaat $e$ learning bagi dunia pendidikan diantaranya: 1. Fleksibelitas tempat dan waktu 2. Independent learning 3. Hemat biaya 4. Fleksibelitas kecepatan pembelajaran 5. Tersedianya sumber-sumber pembelajaran yang tidak terbatas.

Dalam menjalankan sistem e-learning hal utama yang mendukung kegiatan pembelajaran online ini tentunya adalah teknologi dan digital. Diperlukan beberapa platform digital untuk mendukung kegiatan pembelajaran. Pengajar dan peserta didik dapat membuat kesepakatan bersama serta memilih platform mana yang akan digunakan. Di era ini, sudah banyak media e-learning yang tersedia untuk mendukung kegiatan pembelajaran secara online. Terdapat media yang bisa membantu kita untuk melakukan pembelajaran online dengan koferensi video seperti yang tersedia pada zoom meeting dan google meet. Dengan aplikasi ini memungkinkan kita untuk bisa melakukan tanya jawab secara langsung. Kemudian terdapat google classroom sebagai tempat untuk diskusi, 
mengetahui daftar teman kelas, dan memungkinkan kita untuk belajar dimanapun. Selain dari itu, terdapat YouTube yang juga dijadikan wadah untuk melakukan pembelajaran online. Dengan menggunakan aplikasi tersebut, memungkinkan kita untuk mendownload penjelasan materi, memutar ulang penjelesan yang disampaikan, menonton video penjelasan secara offline yang terlebih dahulu sudah di download, melakukan tanya jawab lewat kolom chat yang sudah disediakan. Tak jarang juga tenaga pendidik dan peserta didik nya yang memilih platform seperti whatsapp dan telegram untuk menjalankan kegiatan pembelajaran. Disini, biaya kuota internet yang dikeluarkan cenderung tidak banyak dan lebih dapat digunakan saat jaringan sedang tidak stabil dibandingkan apikasi sebelumya. Pembelajaran seperti tanya jawab biasanya digunakan melalui voice note, diketik pada room chat, atau mengirimkan materi dalam bentuk video maupun file.

\section{b. Sarana Prasarana E-learning Berbasis Self Paced Learning}

Pembelajaran mandiri atau self paced learning memungkinkan peserta belajar kapan saja, dimana saja dengan menggunakan berbagai konten (bahan ajar) yang dirancang khusus untuk belajar mandiri baik bersifat text-based maupun multimedia-based (video, animasi, simulasi, gambar, audio, atau kombinasi dari semuanya. Bahan belajar tersebut, dalam konteks saat ini dapat disampaikan secara online (melalui web maupun melalui mobile device dalam bentuk: streaming audio, streaming video, dan e-book) maupun offline (dalam bentuk CD, dan cetak) (Elisa, Pengertian Blended Learning, 2016).

Selain dari itu, e-learning pada umumnya yang menggunakan media aplikasi digital pendukung pembelajaran mulai dari zoom meeting, google meet, google classroom, YouTube, whatsapp, telegram, edomodo, moodle, quipper, hingga zenius.

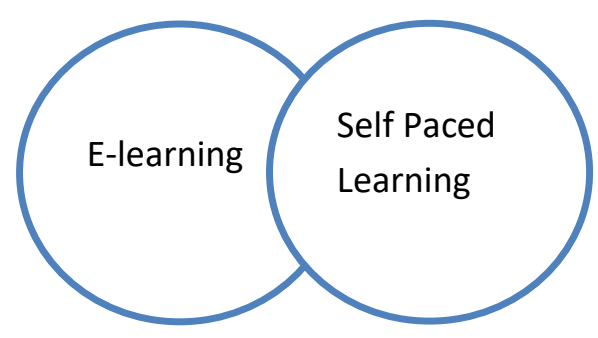

Gambar. 1 Keterkaitan E-learning dengan Self Paced Learning

\section{c. Teks Eksplanasi}

Dalam pembelajaran Bahasa Indonesia sangat banyak materi yang dapat menumbuhkan proses berpikir pada peserta didik. Salah satunya adalah teks eksplanasi. 
(Winarsih, 2021) berpendapat mengenai pengertian dari teks eksplanasi adalah teks yang berisi tentang proses 'mengapa' dan 'bagaimana' kejadian-kejadian alam, sosial, ilmu pengetahuan, budaya, dan lainnya yang dapat terjadi. Yang menjadi kajian dari teks eksplanasi adalah fenomena alam maupun fenomena sosial yang pernah terjadi serta bagaimana sebab-akibat dari peristiwa tersebut. Tidak semua teks dapat dikatakan dan dimasukkan kedalam kategori teks eksplanasi. Teks eksplanasi memiliki ciri sebagai berikut: 1. Memuat data dan informasi faktual, 2. Terdapat ilmu pengetahuan, 3. Informatif, 4. Berorientasi pada hal umum.

Teks eksplanasi menjelaskan tentang suatu proses yang terjadi pada fenomena yang telah disebutkan tersebut. Dengan membaca dan melakukan analisis terhadap teks eksplanasi dapat menambah informasi yang detail serta akurat terhadap suatu fenomena alam maupun sosial yang terjadi. Dengan mengamati bacaan, melakukan analisis terhadap teks eksplanasi dapat menjadi sebuah pelajaran serta bagaimana solusi yang dapat diterapkan untuk permasalahan tersebut.

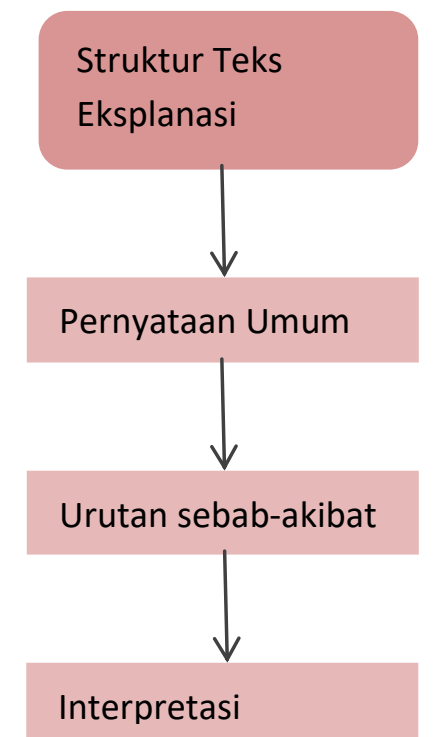

Gambar 2. Struktur Teks Eksplanasi

\section{d. Inovasi E-learning dan Self Paced Learning Pada Teks Eksplanasi}

Sejak pandemi covid-19 pada Maret 2020 lalu mengakibatkan seluruh aktivitas terhambat dan tidak dapat dilakukan secara langsung seperti sebelumnya. Untuk itu seluruh kegiatan terpaksa dilaksanakan secara online. Pemerintah berusaha mengakali bagaimana cara agar aktivitas tetap ada dan dilaksanakan namun pelaksanaannya dilakukan cukup dari rumah dan dilaksanakan secara online. Dampak ini tak terkecuali juga pastinya dirasakan pada bidang pendidikan. Dalam (Zulhafizh, Peran dan Mutu 
Pelaksanaan Pembelajaran oleh Guru di Satuan Pendidikan Tingkat Atas, 2021) selama pelaksanaan pembelajaran berlangsung, kegiatan yang dilakukan guru dibatasi oleh waktu. Setiap mata pelajaran memiliki ragam waktu yang diperlukan. Guru harus bisa memanfaatkan waktu yang ada. Efektivitas waktu pembelajaran sangat penting diperhatikan. Untuk itu, sebelum pembelajaran dilakukan, seorang guru harus membuat perencanaan waktu yang diperlukan untuk setiap aktivitas pembelajaran. Dengan perencanaan tersebut, guru dapat mengelola kegiatan untuk mencapai tujuan pembelajaran.

Salah satu inovasi e-learning yang diharapkan dapat memujudkan hal tersebut adalah menggunakan sistem self paced learning pada pembelajaran teks eksplanasi. Memberikan tugas untuk menganalisis struktur teks, mana yang membuktikan bahwa teks tersebut masuk kedalam teks eksplanasi sebanyak 5 teks eksplanasi mengenai fenomena alam dan sosial yang tejadi kemudian masing-masing dari teks tersebut menggambarkan fenomena alamkah atau fenomena sosial. Peserta didik akan berpikir kritis terkait alasan, struktur teks, dan teks tersebut dikelompokkan kedalam fenomena sosial atau alam.

\section{Sarana Pendukung}

a. Google classroom

b. Google meet

c. Zoom

d. Whatsapp

e. Telegram

f. YouTube

g. Laptop

h. Handphone/Smartphone

i. Kuota internet

j. Jaringan

k. Situs-situs bidang pendidikan

1. Buku cetak

m. Artikel dan website-website terkait

\section{Tindakan Solutif}

a. Jika terdapat peserta didik yang tidak memiliki perangkat laptop maka dapat diganti menggunakan komputer warnet. 
b. Jika peserta didik tidak dapat menggunakan laptop maupun komputer warnet maka dapat diganti menggunakan handphone/smartphone.

c. Jika terdapat peserta didik yang tidak memiliki handphone/smartphone maka dapat meminjam milik keluarga dan orang terdekat.

d. Jika terdapat peserta didik yang tidak memiliki kuota internet maka dapat menggunakan wifi gratis.

e. Jika peserta didik tidak memiliki jaringan yang bagus maka dapat meminta hotspot atau sambungan wifi kepada pemilik jaringan.

f. Jika peserta didik tidak memiliki buku cetak maka dapat diganti dengan menggunakan artikel, jurnal, dan website-website online terkait.

\section{Simpulan}

Sejak pandemi covid-19 mulai mewabah di negara Indonesia, dengan terpaksa pula segala kegiatan yang bersifat tatap muka dengan manusia lain dihentikan sementara. Kemudian, agar proses keberlangsungan hidup tetap berjalan semestinya, beberapa sektor mulai mengalihkan kegiatannya secara online. Termasuk untuk kegiatan pembelajaran. Dalam menjalankan sistem e-learning hal utama yang mendukung kegiatan pembelajaran online ini tentunya adalah teknologi dan digital. Diperlukan beberapa platform digital untuk mendukung kegiatan pembelajaran. Pengajar dan peserta didik dapat membuat kesepakatan bersama serta memilih platform mana yang akan digunakan.

Salah satu inovasi e-learning yang diharapkan dapat memujudkan hal tersebut adalah menggunakan sistem self paced learning pada pembelajaran teks eksplanasi. Memberikan tugas untuk menganalisis struktur teks, mana yang membuktikan bahwa teks tersebut masuk kedalam teks eksplanasi sebanyak 5 teks eksplanasi mengenai fenomena alam dan sosial yang tejadi kemudian masing-masing dari teks tersebut menggambarkan fenomena alamkah atau fenomena sosial.

\section{Referensi}

Anjani, A. (2021, Oktober 28). Teks Eksplanasi: Pengertian, Ciri, Struktur, dan Contohnya. detikEdu, hal. 1.

Elisa, E. (2016, Juli 15). Pengertian Blended Learning. Blended Learning, hal. 1.

Hartanto, W. (2016). Penggunaan E-learning Sebagai Media Pembelajaran. JPE, 8-9. 
Winarsih, A. A. (2021, September 25). Apa yang Dimaksud Dengan Teks Eksplanasi. Media Indonesia, hal. 1-2.

Zulhafizh. (2020). Membina Aktivitas Belajar Mahasiswa di Perguruan Tinggi. Jurnal Kependidikan, 502-11

Zulhafizh. (2021). Peran dan Mutu Pelaksanaan Pembelajaran oleh Guru di Satuan Pendidikan Tingkat Atas. Jurnal Kependidikan, Vol.7 No.5, 328-339 
*Data Penulis

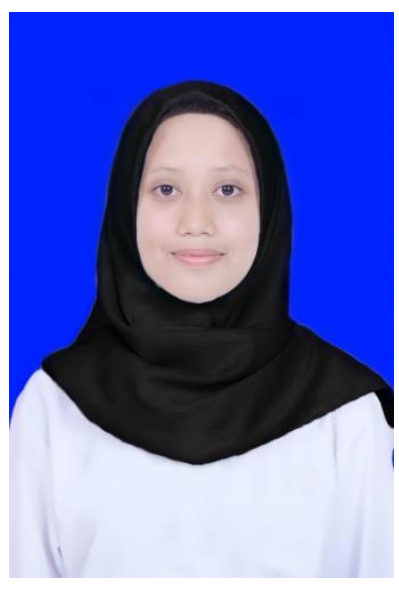

Yana Lisa Warni, lahir di Duri, 26 Desember 2001. Ia merupakan anak ketiga dari tiga bersaudara. Pada tahun akademik 2020, ia lulus dari SMAN 2 Mandau. Kemudian, ditahun yang sama ia melanjutkan studi pada strata satu Jurusan Pendidikan Bahasa dan Seni di Program Studi Pendidikan Bahasa dan Sastra Indonesia FKIP Universitas Riau melalui jalur SBMPTN (Seleksi Bersama Masuk Perguruan Tinggi Negeri). Terdapat beberapa prestasi yang pernah ia peroleh salah satunya adalah lulus tes dan mendanat heasiswa dari OSC.

Kontak:

Hp/WA : +62895601519990

Email : yanalisawarni@gmail.com 